\title{
Molecular detection of Hammondia heydorni in dogs in Mosul city
}

\author{
W.A. Alobaidii \\ Department of Microbiology, College of Veterinary Medicine, University of Mosul, Mosul, Iraq \\ Email: wasenamjad@yahoo.com
}

(Received August 28, 2019; Accepted September 20, 2019; Available online June 12, 2020)

\begin{abstract}
Through this study 122 individual fecal samples were collected from dogs, with different ages, sexes, and breeding management (stray and pet house hold). Some dogs were with healthy appearances while others were suffered from diarrhea, anorexia, depression, dehydration. Infection was investigated by light microscope after flotation technique by using Sheather's sugar solution. if the sample gives positive to oocyst ( $H$. heydorni or other relative group), were mixed with potassium dichromate solution a rate of $2.5 \%$ for the stimulation of sporulation. DNA extraction was done using $2 \%$ sarcosyl, pronase $\mathrm{E}$ followed by phenol/chloroform extraction then precipitation attempt using ethanol. DNA amplification was attempt using $H$. heydorni primers JS4 and JS5 n microscope examination give 78 sample positives to the presence of oocyst, while polymerase chain reaction showed total percentage of infection with $H$. heydorni was $34.6 \%$ (27 case give positive reaction to PCR). Dogs less than 6 months of age show high infective rate 17.9\%, dogs which suffer from gastrointestinal tract troubles (diarrhea, anorexia and dehydration) gave high infective rate $24.4 \%$. Stray dogs gave high prevalence of infection to $H$. heydorni $25.6 \%$ when compared with pet house hold dogs which recorded 9\% percentage of infection. This study is the first recorded $H$. heydorni in dogs in Mosul city.
\end{abstract}

Keywords: H. heydorni, Stray dogs, Pet dogs, Mosul

DOI: 10.33899/ijvs.2019.126052.1219, ( 2020, College of Veterinary Medicine, University of Mosul.

This is an open access article under the CC BY 4.0 license (http://creativecommons.org/licenses/by/4.0/).

\section{الكثف الجزيئي عن طفيلي Hammondia heydorni في الكلاب في مدينة الموصل}

$$
\text { فرع الأحياء المجهرية، كلية الطب البيطري، جامعة الموصل، الموصل، العراق العبيدي }
$$

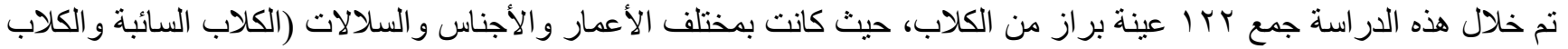

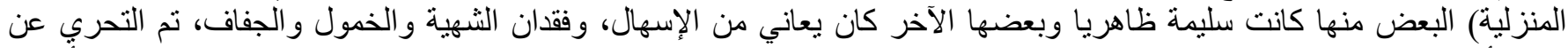

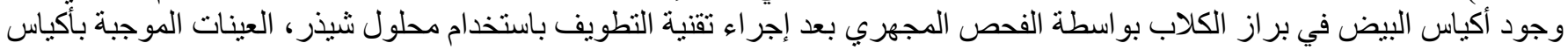

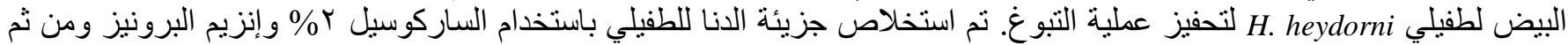

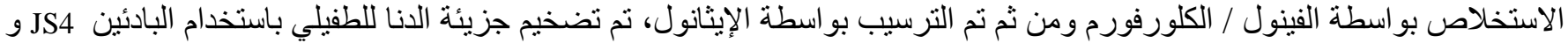
و و المصممين من الجين ITS5

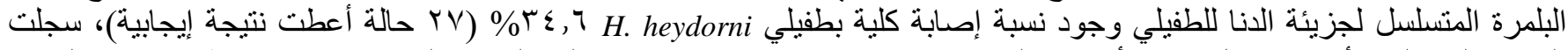

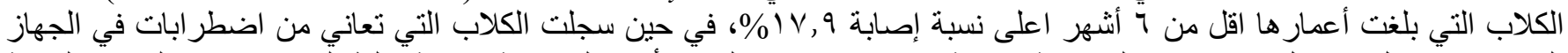

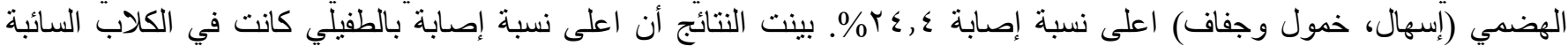

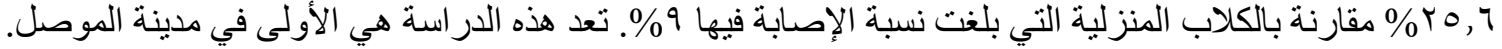




\section{Introduction}

H. heydorni is a coccidian obligatory parasite, the life cycle needs 2 hosts, the dogs and other wild candies is a definitive host, a numerous of herbivores is an intermediate host (1). Sexual reproduction and oocyst production occur in definitive hosts. The pre patent period is 1-3 weeks. The intermediate hosts can be infected by the ingestion of sporulated oocysts.

Definitive hosts become infected only after eating tissue cysts $(2,3)$. Oocyst can excrete by definitive hosts and sporulated within 3 days (4). The infection with $H$. heydorni of the definitive hosts is characterized by subclinical course, some times the animals suffer from anorexia, severe diarrhea or recurrent diarrhea, unresponsive specially in puppies and immune compromised dogs, sometimes neurological signs have been observed (5).

Distinguishing of oocyst of the relative group of $H$. heydorni which include Neospora caninum and Toxoplasma gondii is so difficult $(6,7)$, so that the differentiation between oocyst of these species using routine microscopic technique give inexact results (8). In order to detect the infection of $H$. heydorni a variable technique can be used which include serological and molecular technique $(9,10)$, polymerase chain reaction is the best method for the detection and identification this coccidian parasite (11). The spacer internal transcribed spacer (ITS) can be used as genetic markers to detect this species of parasites (8).

This spacer is varied between $H$. heydorni and other coccidian parasites so this spacer can be used to discrimination between them (12).

\section{Materials and methods}

\section{Fecal samples and morphological study of oocysts}

This study was achieved in Mosul University, College of Veterinary Medicine, during the period from January 2019 to June 2019. A One-hundred and twenty individual fecal samples were collected from dogs with different ages, sexes, and breeds management (stray and house hold). Some animals healthy in their appearance and while others were suffering from diarrhea, anorexia, depression, dehydration.

The samples were examined to investigate the presence of oocysts by using light microscope after flotation technique was done using Sheather's sugar solution. if the sample gives positive to oocysts $(H$. heydorni relative group), were add to potassium dichromate solution a rate of $2.5 \%$ for the stimulation the sporulation in petri dishes at a room temperature for 10 days, sporulated oocyst were collected and purified by centrifugation and preserved at $4^{\circ} \mathrm{C}(8)$.

\section{DNA extraction}

A $0.5 \mathrm{ml}$ of each sample was blended with $1.5 \mathrm{~mL}$ of phosphate-buffered saline, then centrifuged at $14.000 \mathrm{~g}$ for 3 minutes. the Precipitate materials were washed 3 times in phosphate buffer saline and combined with $1.5 \mathrm{ml}$ in micro tubes half hour. DNA was extracted with $2 \%$ sarcosyl (Merck), pronase E (Roche and with phenol/chloroform extraction then sedimentation attempt accomplished by using ethanol (13), DNA dissolved in RNA, DNA free water and preserve at $-20^{\circ} \mathrm{C}$.

\section{DNA amplification}

$H$. heydorni primers designed according to ITS1 sequences. The primers JS4 (5 -CGA AAT GGG AAG TTT TGT GAA C-3) and JS5 (5-CAG CAG CTA CAT ACG TAG A-3) (Sigma Aldrich, Germany). reactions was done at $25 \mathrm{uL}$, the reaction include $25-100$ pmol of two primers, dNTPs, buffer 1-2U Taq polymerase reaction mix contain 25-100 pmol of each primer, reaction buffer, dNTPs, and 0.5-2U of Taq DNA polymerase (D 1806 Sigma-Aldrich) and 1 ul of DNA sample (8), ten amplification attempt in thermocyclers at the program listed in table 1 were applied, size of the amplification products was $270 \mathrm{bp}$, then those products detected by using electrophoresis in a $2 \%$ agarose gel and ethidium bromide.

Table 1: Program of DNA amplification of $H$. heydorni using thermocycler

\begin{tabular}{lccc}
\hline Step & $\begin{array}{c}\text { Temperature } \\
\left({ }^{\circ} \mathrm{C}\right)\end{array}$ & $\begin{array}{c}\text { Time } \\
(\text { minutes })\end{array}$ & Cycles \\
\hline Initial Denaturation & $95^{\circ} \mathrm{C}$ & 5 & 1 \\
Denaturation & $95^{\circ} \mathrm{C}$ & 1 & \\
Annealing & $65^{\circ} \mathrm{C}$ & 1 & 35 \\
Extension & $72^{\circ} \mathrm{C}$ & 1.5 & \\
Final Extension & $72^{\circ} \mathrm{C}$ & 10 & 1 \\
\hline
\end{tabular}

\section{Results}

The results of sporulation and light microscope examination give 78 sample positive to the presence of oocyst, the DNA amplification were positive which revealed as band in 270 bp (Figure 1), the results showed total percentage of infection with $H$. heydorni is $34.6 \%$ (27 case give positive reaction to PCR), animals less than 6 months of age recorded high infective rate $17.9 \%$ while the lowest percentage of infection showed in animals more than 1 year of age (Table 2). The dogs which suffer from gastrointestinal tract troubles included diarrhea, anorexia and dehydration gives high infective rate $24.4 \%$ when compare with healthy dogs which showed $10.2 \%$ percentage of infection (Table 3 ). 

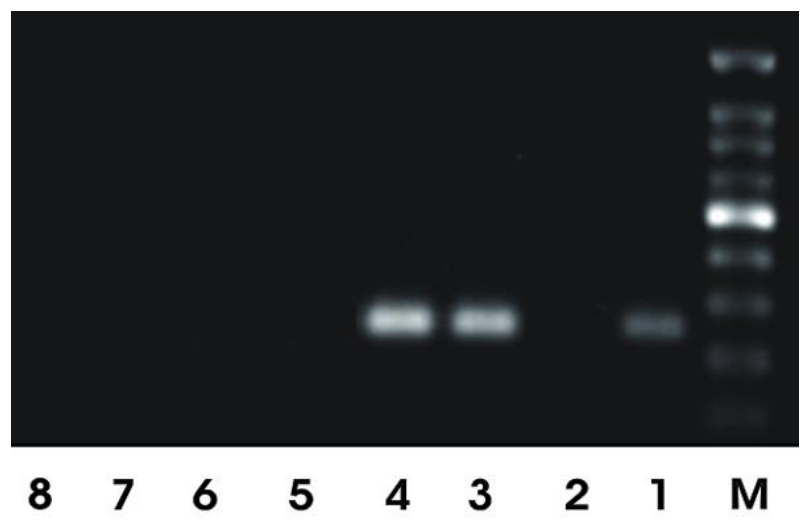

Figure 1: Result of electrophoresis of DNA products, $\mathrm{M}=$ marker, 1,3 and 4 positive samples, 2,5-8 negative samples

Table 2: Percentage of infection of $H$. heydorni in dogs using PCR according to age

\begin{tabular}{lcccc}
\hline & \multicolumn{3}{c}{ Age (months) } & \multirow{2}{*}{ Total } \\
\cline { 2 - 4 } & $>6$ & $6-12$ & $<12$ & \\
\hline $\begin{array}{l}\text { Samples positive to } \\
\text { H. heydorni or }\end{array}$ & 33 & 26 & 19 & 78 \\
$\begin{array}{l}\text { relative group n } \\
\text { Samples positive }\end{array}$ & 14 & 8 & 5 & 27 \\
by PCR n (\%) & $(17.9)$ & $(10.3)$ & $(6.4)$ & $(34.6)$ \\
Samples negative & 19 & 18 & 14 & 51 \\
by PCR n (\%) & $(15)$ & $(15.7)$ & $(12.6)$ & $(65.4)$ \\
\hline
\end{tabular}

Table 3: Percentage of infection of $H$. heydorni in dogs using PCR according to Health status

\begin{tabular}{|c|c|c|c|}
\hline & \multicolumn{2}{|c|}{ Health status } & \multirow{2}{*}{ Total } \\
\hline & Sick & Healthy & \\
\hline $\begin{array}{l}\text { Samples positive to } \\
H \text {. heydorni or } \\
\text { relative group } \mathrm{n}\end{array}$ & 47 & 31 & 78 \\
\hline $\begin{array}{l}\text { Samples positive } \\
\text { by PCR n }(\%)\end{array}$ & $\begin{array}{c}19 \\
(24.4)\end{array}$ & $\begin{array}{c}8 \\
(10.2)\end{array}$ & $\begin{array}{c}27 \\
(34.6)\end{array}$ \\
\hline $\begin{array}{l}\text { Samples negative } \\
\text { by PCR } \mathrm{n}(\%)\end{array}$ & $\begin{array}{c}28 \\
(35.9)\end{array}$ & $\begin{array}{c}23 \\
(29.5)\end{array}$ & $\begin{array}{c}51 \\
(65.4)\end{array}$ \\
\hline
\end{tabular}

Stray dogs give high prevalence of infections $H$. heydorni $25.6 \%$ when compared with house hold dogs which recorded $9 \%$ percentage of infection (Table 4).

\section{Discussion}

There are no studies indicating the presence $H$. heydorni in dogs in Mosul city, so this study was done to determine the H. heydorni based on the detection of parasite DNA.
Table 4: Percentage of infection of $H$. heydorni in dogs using PCR according to Type of dog management

\begin{tabular}{lccc}
\hline & \multicolumn{2}{c}{ Dog management type } & \multirow{2}{*}{ Total } \\
\cline { 2 - 3 } & Stray & House hold & \\
\hline $\begin{array}{l}\text { Samples positive to } \\
\text { H. heydorni or }\end{array}$ & 47 & 31 & 78 \\
relative group n & & & \\
Samples positive & 20 & 7 & 27 \\
by PCR n (\%) & $(25.6)$ & $(9)$ & $(34.6)$ \\
Samples negative & 27 & 24 & 51 \\
by PCR n $(\%)$ & $(34.6)$ & $(30.8)$ & $(65.4)$ \\
\hline
\end{tabular}

This study showed total percentage of infection with $H$. heydorni is $34.6 \%$ (27 case give positive reaction to PCR), and high prevalence of infection in dogs less than 6 months and lowest percentage showed in more than 1 year of age. Few studies dole out the relationship between the prevalence of infection of $H$. heydorni and the age of dogs, (14) recorded high prevalence of infection to $H$. heydorni in dogs 3-6 months of age, while (15) reported the prevalence of infection of $H$. heydorni was $2.7 \%$ from 481 fecal sample of dogs, Muhammed (16) reported high prevalence of infection in dogs 1-4 years old and lower percentage in older dogs, (17) reported affected dogs are generally less than six months old, the reasons of increase the percentage of infection younger animals is the nature infection of $H$. heydorni in the definitive hosts which take subclinical form specially in younger and immunosuppressed animals (5), younger dogs immune system can exposed to several etiological microorganisms which cause immune suppression which lead to allow $H$. heydorni to invade gastrointestinal tracts infection and appearing clinical signs.

High infective rate in animals suffer from gastrointestinal tract troubles, Abel (1) report that the infection of $H$. heydorni is increasingly becoming associated with diarrhea and gastrointestinal tract problem, Webb (18) found the oocyst of $H$. heydorni in feces of a dog suffer from intermittent bouts diarrhea this dog already been treated with immunosuppressive treatment. Stray dogs give higher prevalence of infection with $H$. heydorni when compared with pet house hold dogs, the reason of that is due to periodic vaccination program and preventive medicine to another parasitic disease in pet housed dogs, which lead to decrease the possibility of immune suppression, another reason is the use of commercial dog food to feeding the pet dogs while stray dogs are free feeding (19). In contrast to the stray dogs, pet dog health care is crucial in terms of veterinary follow-up with periodic antiparasitic treatment (20).

The role of veterinarian visits has an important role in the reduction of disease occurrence. Our results confirm this hypothesis, since recurrent visits to the veterinary 
clinics by pet dog owners has a positive impact on the health of their animals.

\section{Conclusions}

Hammondia heydorni was affected dogs more than 1 year of age and in dogs suffer from GIT troubles and this parasite was first recorded in dogs in Mosul city.

\section{Acknowledgment}

The author wish to thank College of Veterinary Medicine, University of Mosul for financially supporting this work, laboratory of veterinary teaching hospital, for their support and the animal's owners for their cooperation

\section{Conflict of interest}

Authors declare no conflict of interests of the manuscript.

\section{References}

1. Abel J, Schares GK, Orzesko K Gasser RB, Ellis J. Hammondia isolated from dogs and foxes are genetically distinct. Parasitol. 2006;132:187-192. Doi: $10.1017 /$ S0031182005008814

2. Wadajkar SV, Shastri UV, Narladkar BW. Transmission of Hammondia heydorni to guinea pigs and rabbits via dog. J Appl Anim Res. 1994;5:77-79. Doi: 10.1080/09712119.1994.9706001

3. Schares G, Pantchev N, Barutzki D, Heydorn AO, Bauer C, Conraths FJ. Oocysts of Neospora caninum, Hammondia heydorni, Toxoplasma gondii and Hammondia hammondi in faeces collected from dogs in Germany. Int J Parasitol. 2005;35(14):1525-1537. Doi: 10.1016/j.ijpara.2005.08.008

4. Dubey JP, Dolores EH, David SL, Mark CJ, Arvid U, Clarence A. Neospora caninum and Hammondia heydorni are separate species. Parasitol. 2002;18(2):66-69. Doi: 10.1016/S1471-4922(01)02172-9

5. Steffl M, Nautscher N. Detection of Hammondia heydorni-like oocysts in feces of a dog with recurrent diarrhea. Tierarztl Prax. 2019;47(3):189-192. Doi: 10.1055/a-0890-2350

6. Schares G, Heydorn AO, Cüppers A, Conraths FJ, Mehlhorn H. Hammondia heydorni-like oocysts shed by a naturally infected dog and Neospora caninum NC-1 cannot be distinguished. Parasitol Res. 2001;87(10):808-816. Doi: 10.1007/s004360100445

7. Nancy BM, David A, Anja R, Alan M, Astrid M, Tenter J. Phylogenetic analysis based on full-length large subunit ribosomal
RNA gene sequence comparison reveals that Neospora caninum is more closely related to Hammondia heydorni than to Toxoplasma gondii. Inter J Parasitol. 1999;29:1545-1556. Doi: 10.1016/s00207519(99)00150-2

8. Slapeta JR, Koudela B, Votýpka J, Modrý D, Horejs R, Lukes J. Coprodiagnosis of Hammondia heydorni in dogs by PCR based amplification of ITS 1 rRNA: differentiation from morphologically indistinguishable oocysts of Neospora caninum. Vet J. 2002;163(2):147-154. Doi: 10.1053/tvjl.2001.0599

9. Dubey JP, Sreekumar C, Miska KB, Hill DE, Vianna MCB, Lindsay DS. Molecular and biological characterization of Hammondia heydorni-Like oocysts from a dog fed hearts from naturally infected white-tailed deer (Odocoileus virginianus). J Parasitol. 2004;90(5):1174-1176. Doi: 10.1645/GE-324R

10. Razmi GR. Survey of dogs' parasites in Khorasan Razavi Province Iran. Iranian J Parasitol. 2009;4(4):48-54. [Available here]

11. Sreekumar DE, Hill VM, Fournet BM, Rosenthal LD, Dubey JP. Detection of Hammondia heydorni-like organisms and their differentiation from Neospora caninum using random-amplified polymorphic DNA-polymerase chain reaction. J Parasitol. 2003;89(5):1082-1085. Doi: 10.1645/GE-93R

12. Ellis T, Pomroy W. Hammondia heydorni oocysts in the faeces of a greyhound in New Zealand. N Zeal Vet J. 2003; 51(1):38-39. Doi: 10.1080/00480169.2003.36328

13. Masolv DA, Lukesae J, Jirku M, Simpson L. Phylogeny of trypanosomes as inferred from the small and large subunit rRNAs: implications for the evolution of parasitism in the trypanosomatid protozoa. Mol Biochem Parasitol. 1996;75:197-205. Doi: 10.1016/0166-6851(95)02526-X

14. Barutzki D, Schaper R. Results of parasitological examinations of faecal samples from cats and dogs in Germany between 2003 and 2010. Parasitol Res. 2011;109(1):45-60. Doi: 10.1007/s00436-0112402-8

15. McKenna B, Charleston AG. Coccidia (protozoa: sporozoasida) of cats and dogs IV. Identity and prevalence in dogs. N Zeal Vet J. 1980;28(7):128-130. Doi:10.1080/00480169.1980.34722

16. Muhammed OM. Prevalence study of Isospora spp, Hammondia heydorni in dogs in Al-Muthana province. Kufa J Vet Med Sci. 2012;3(2):84-90. [Available here]

17. Reichel MP, Ellis JT, Dubey JP. Neosporosis and hammondiosis in dogs. J Small Anim Pract. 2007;48(6):308-312 Doi: 10.1111/j.17485827.2006.00236.X

18. Webb JA, Keller SL, Southorn EP, Armstrong J, Allen DG, Peregrine AS, Dubey JP. Cutaneous manifestations of disseminated toxoplasmosis in an immunosuppressed dog. J Am Anim Hosp Assoc. 2005;41:198-202. Doi: 10.5326/0410198

19. Alobaidii WA, Rafal LA, Maryam AA. Detection of blood protozoa in pet dogs in Nineveh province. Assiut Vet Med J. 2019;65(162):1-8. [Available here]

20. Alobaidii W. The serological diagnosis of Leishmaniasis in dogs by using ELISA in Nineveh province. Iraqi J Vet Sci. 2019; 33(2):111114. Doi: $10.33899 /$ ijvs.2019.163194 